\title{
Faik Konica's Contribution in the Language and Some Phonetic and Orthographic Features in His Prose
}

\author{
Dr. Rakela Luniku \\ "Aleksandër Xhuvani" University, Department of Linguistics, Rinia St. Elbasan, Albania \\ rluniku@gmail.com
}

\section{Doi:10.5901/ajis.2015.v4n1s2p183}

\begin{abstract}
The article aims to highlight the phonetic and orthographic features of Konica's prose, who was a prominent forerunner of today's Albanian literary language orthography. It needs to be highlighted that the Albanian phonological system is not the same as a century ago, because the uninterrupted flow of language evolution has experienced at times a disappearance of the phonemes, phoneme conversions or creation of new phonemes. Therefore we think that some linguistic dilemma expressed by the author are more than justified for that period of time when the Albanian language did not have a crystallized orthographic norm.
\end{abstract}

Keywords: phonologic system, possessive articles, voiceless consonants.

\section{Introduction}

The language constantly evolves and changes in the course of centuries. In its evolution spanning millennia, words, grammatical forms and phonemes change, and their change happens much more slowly compared to other elements of the language. Thus, if we take a diachronic look on the Albanian language since from the time when the first work in Albanian was published (Missal of John Buzuku, 1555) until the present day, we will notice that the Albanian vocabulary has undergone many changes, somewhat less changes can be viewed on grammatical forms, while phonemes have remained almost unchanged.

However, it should be noted that the foundations of today's spelling system were cast in the nineteenth century, during the Renaissance period. The main aim was the creation of an elaborate literary language, stabilized and unified, so as to raise the Albanian language at the level of a developed language culture. The first efforts to address and discuss specific issues of the Albanian orthography are found at the magazine "Albania" during the period (1897 -1909), which was led by Faik Konica.

The magazine attracted the attention of many scholars of the time on issues regarding the alphabet and spelling, instilling an Albanian spelling system, literary language issues, the merger of the two dialects, etc.

* Analyzing his correspondence throughout the years, we have noticed that the author makes a wide use of the stress, especially on the vowel ( e ) (which should definitely be a French influence).

létrën tëndé é muarmë vésh, dhé në émër të së Përkohëshmés ju propozojmë...; as na bën ghëséndi é léhura é tyré kundrë névé...;

të jam i détyruar për urimét cë më bëré për motin e ri...; (Konica, 2006)

* With regards to the use of the aphostrophy ( mainly on the voiceless vowels ), Konica faithfully continued the spelling traditions of the Southern literary language as a pronunciation trait of this dialect. The vowel drops frequently happen in the spoken language and consequently even in the written one, whenever two vowels come into contact with one another, thus when one word ends and the other starts with a vowel. Under these circumstances, due to the stress dynamism, one of these vowels is omitted. The lost sound could be in different positions in the word : at the end( elision ), at the front ( afereza ), or in its body( sinkopa ). (Topalli, 1995 )

The most frequently dropped vowel is the -ë, which is characterized by a faint pronunciation, though there have been found cases of other vowel omissions such as: $i$, a , etc .

Elision is mostly found in Konica in these cases: 
a) In all his writings, literary or journalistic, he regulary uses the apostrophy when the final unstressed -ë is dropped in words situated in front of the vowel -e (which can be an article of the genitive case or an article of the adjective and rarely a linker that begins with a vowel):

perëndia qoft' e lëvduar ; historin' e zulluve ; për mjeshtërin' e qepëtorit ; fuqin' e fjalës ;

fuqit' e mbëdha ; perëndit' e vjetëra ; mbrëm' e sipër ; vëllan' e vatanë ;

The usage of the apostrophe not only by Konica, but also by other authors, northern or southern, is linked with the pronunciation characteristic of our language. Albanian, being a language in which the stress is positioned at the penultimate syllable, has the tendency to omit the last syllable during the pronunciation and consequently even during the writing process.

b) It has frequently been noted that some single syllable proklitik words such as: particles, frontal articles, prepositions, the conditional conjunction ( në ), or the relative pronoun

( që ), whenever they are positioned in front of the words that begin with a vowel:

n' udhëra t' lirisë e t'Athinës ; n' arthçin mbë këmbë ; n'atë kohë n'Avrop;

q' i shkruante s' ëmës ; i veprave t' ergjëndarëve ; në kohë t' Ali pashë Tepelenit ; n' imitojnë shkollën e Venedikut ; u - takuan nd' udhë ; nukë janë mb' udhë të dreqtë ; m' i forti burrë ;

c) Elision has also been noted in some cases when the particle ( të ) of the relative is placed in front of a verb that begins with a vowel, or even in front of a short form:

që t' ujdiste ; për t' admiruar ; me t' ardhur ; për t' ushqyer ;

t'i shërbenjë mëmëdheut; qi t' armatoste Veriun; po t'ish burr' i besës ;

This is a phenomenon that has regularly appeared since from the beginnings of the written tradition of the Albanian language. It has also been found in the short pronoun forms or with the particle $-\mathbf{u}$ of the passive reflective and is noted since from the time of Buzuku, Budi, Bogdani, etc :

t' ap të ditunë ; t' ish ardhunë ; t'u bekonjë juve ; t'i shpie ndë dhet të tyne ; (Topalli, 1995)

d) The elision is still implemented in the Albanian literature today. In the case when the particle (të) merges with the short forms, Konica and other northern writers have been forerunners of today's spelling system. We have also found some cases, although rarer ones, when the author has apostrophized the defining name suffixes, primarily the $-i$, and more rarely the final $-a$.

stërnip'i Tepelenit ; trup'i Shegës ; bel' i saj ; perandoresh' e Stambollit; e bukr' e dheut;

e) There can be observed some other cases of the apostrophized final -ë of names in the feminine gender of the subjunctive case, rarely of the ablative case, before the front article -së :

i bukuris' së Polonjës ; e mençuris' së Herodotit ; e bujaris' së shqiptarëve ;

të historis' së Kastriotëve ; prej butësis' së saj ; prej urtis' së Vatrës ;

We think that it is pronunciation that has deeply influenced in these cases, which tends to omit the final -ë, and which has been portrayed even in writing.

* But Konica mostly prefers to omit the frontal article së together with the drop of the final vowel in nouns, in order to avoid the confrontation of the two së $-s$ :

poshtërimin e mjeshtëris' petkave shqipëtare; varfërin' e veshjes saj;

grekët e Shqipëris' Poshtme ; t'i përunjemi oxhakësis' Tepelenës ;

indipendencës Shqipërisë; shtypjes letrave shqipe;

f) The author widely uses elision even when writing various pronouns such as :

( linkers, which we presented above as prolictic, one-syllable words, indefinite possessives, short forms or joined forms of the personal pronoun )

* in pronouns used for the first and second person in their indirect cases:

* mohimi i gjuhës s' onë; stërgjyshët t' uaj; me vete t'ime; armiqve t' anë ;

* vëllaj $\dot{L}^{\prime}$ uaj; kombësinë t' onë; gabimin t'ënt; artikullin $\underline{t^{\prime} i m \text {; }}$ 


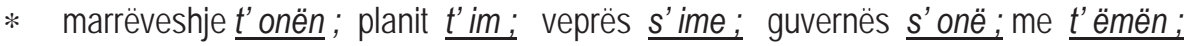

1 A widely discussed issue in his writings is the spelling of the unstressed $\ddot{e}$, which has been and still is a crucial problem for the Albanian language orthography. Being a tosk writer, together with other writers of his time such as Naimi, Noli etc , Konica has the tendency to preserve the unstressed ë and he does never quit widely using the final $\ddot{e}$.

të sunetisurë ; i vetëmë ; të pagëzuarë ; të pa- punëshmë ; të zëmëruarë ;

të larguarë ; të zgjaturë ; i varfërë ; me thonjë ; kuajtë ; në zëmërë ;

nukë; aqë ; pakë; nënë sundimin e tij ; etj.

In the literary spelling it can be found the tendency that the final ë is not pronounced, or it is vaguely pronounced, depending on the pronunciation styles.

Nevertheless, in parts of the Southern speech the final ë is still preserved especially in prononcuation, though it is highly reduced. (Çeliku, 1971)

* We have also compared another group of words which in the writer's writings are regularly written with the final - ë such as:

motrë ; librë ; kodrë ; letrëtyrë ; zëmrë ; letrë ; veprë ; sedrë ; theatrë ;

lundrë ; veglë ; lodrë ; të ëmblë ; i bukurë ; i varfërë ; kundrë ; afërë ;

tepërë ; si edhe dy emra qytetesh : Gjirokastrë ; Shkodrë ;

In reality, the old Albanian language has historically possessed the final ë, especially found in the tosk dialect and this is the reason why the writer cannot make an exception from this tendency.

Nevertheless, we think there could be another reason in its usage in regard to this group of words.

It is not occasional that we have cited all the cases we have been able to find, because we think that Konica has been widely influenced by the French language with which he had become so familiar. These words are so similar to French in their pronunciation, and some of them even in their spelling such as: librë (livrë ):

letrë (lèttrë ); theatrë ( theatrë ); kundrë ( contrë); (Konica, "La langue des fils de l'aigle ", 1921)

* With regards to the frontalstressed ë, we notice a correct usage of it, by forerunning today's spelling system:

kombëtar; atëror; armiqësi; ligësi; mjekësor; miqësor; robëroj, mbretëri,

Similarly to a real linguist, he puts a sustaining ë- in front of those suffixes that start with a consonant, so as to avoid the difficulty arising in their prononcuation, particularly when two or more consonants occur in its body.(" Drejtshkrimi i gjuhës shqipe", 1973 )

On the contrary, we would have: ligsi ; robroj ; kombtar ; etj .

In today's collocation style the $-\ddot{e}$ in this position has been transformed into a short sound which represents a voiceless vowel, while in today's spelling it has totally been avoided, because by doing so we can create consonant groups which are easily pronounced. (Totoni, 1972)

* With regards to the $e$ - vowel spelling, in those words where this phoneme is followed by a nasal consonant $m,-n,-n j$, Konica prefers to write it without any doubt with the ë- vowel.

zëmrën e kish të ngrysur; të thotë ç'i do zëmbëra ; të shkrojë ç’i do zëmbëra ;

të bëjë ç'i do zëmbëra; veç jo ato që janë kundrë lirisë tjatëri njeriu ; vënd ; mbaj mënd ;

brënda në kishë ; trëmben ; ëngjëjt ; në qëndër; më dhëmp; gjëmp; dhëmp i lik: (Konica, "Ç'është liria ", 1897)

An important role has been played by the close collaboration of the two Albanian dialects in creating abasis for the prononucation as well as the spelling system in this language. (Gjinari, 1963)

* Another evident characteristic of Konica and tosk dialect in general is the presence of the -ua diphthong in all positions, in open and closed syllables.

In the majority of the cases this vowel group is represented as unassimilated, in difference from the gege dialect where it is assimilated in - $u$ ( grua - gru ; përrua - prru ; )

ish një shqipëtar i pasur e i letruar ; Toskua kish mbetur nënë dritare ;

esperantua është proponuar si zgjidhje e mirë ; Moskua e kapi për xverku ; 
* This unassimilated diphthong is widely used by Konica in the verbs of the past simple in the three persons of the plural.

u - mbluadhnë në metropoli ; e zgjuadhnë patrik ; i muarnë

or in some nouns which normally require the suffix -or:

i mbuluar gjer në kraharuar, po këndon një librë ;

qysh nukë pati turp të dalë tradhëtuar, grabitës e zuzar ; (Gjinari, "Mbi të folmen e Devollit ", 1968)

* Nevertheless, from time to time the author is ambiguous in the usage of this group of vowels, because we have come across many cases when the diphthong -ua has been assimilated into - 0

kish një mikeshë të qojtur Vera ; për shojtjen e një yllit aq të ndritshëm ;

propagandë për të vetëqojturën guvernë ; $u$ - përball me turmën e parojtur;

Linkoln - i rojti pakë viet, por i qojti gjithë skllevët të lirë ;

* The author frequently uses the $-u$ vowel in stead of the vowel $-y$ :

pas musafirëve ; s' i durojnë gjukimet ; nukë hyn njeri në duqane ;

kur qe mutesarif; dushoj te zotësia jime ; popull musliman ; huqumeti ;

ç' gjuqe të pafajshëma ; duke dëftuar virtut ; njerës të rushfetit ;

We have encounter numerous similar words, which testify about the great influence that has been exercised by his mother tongue :çamërishtja in his linguistic formation, though he had been detached from its usage since from an early age.

* Another evident characteristic of almost all the Renaissance writers, of which the author makes no exception, was the phenomenon of the voiceless consonant which had once been voiced, when they are situated in a final position or in front of a voiceless consonant in the body of the word, which is not noticed only in the Albanian language, but even in some other Indo-European languages.

In the tosk dialect, this phenomenon must have appeared since in the Middle ages, because in the dialects of the Albanians living in Italy and Greece this voicelessness is shown to be completed. Norbert Jokli states that it could be even older since he compares it to a phenomenon similar to Etruscan language. (Çabej, "Studime rreth etimologjisë së gjuhës shqipe", 1960)

The phenomenon of the voiceless consonants is typical of the tosk dialect, though it should not be over generalized, because cases of such can also be found in the Northern dialect.

Konica remains faithful to the tradition and he is convinced that the spelling of a language should not be different from its pronunciation something which is typical of the language used in his writings.

Similarly, other Renaissance writers have written the voiceless consonants at the end or body of the word just as they pronounced them: in the gegë dialect they conserved them as voiced, while in the tosk dialect they wrote them as voiceless. (Dodi, 1970)

\section{The Voiceless Consonants at The end of the Word}

- $\quad$ The voiced consonant -dh- is always written -th- :

lith; i math; derth; heth; u ndoth; vjeth; garth; u çloth; i erth një letër; u- zgjoth; etj.

The voiced consonant $-b$ - is always written as $-p-$ :

komp; i dhëmp në shpirt; gjëmp i math ; hoqi një dhëmp; hump besimin e guvernës; sërp i fëlliqur ; u kalp; u zu rop; qelp; etj.

- $\quad$ The voiced consonant - $d$ - is always written as -t- :

në vënt të ; munt të qëndronjë; kam nër mënt; u shkunt; u munt; funt i keq;

si edhe numërorët njëqint ; treqint ; pesëqint ; nëntëqint ; etj.

- The voiced consonant $-g$ - is always written as - $k-$ : 
pellask; frënk; trek i math; i lik; kolek; lark; shtek; një tok shënimesh; zok pa liri;etj

- The voiced consonant -z- is always written as -s- :

njerës; gas; në kurris; në kafas; serios; ndes; me një bres të kuq; haus; etj

- $\quad$ The voiced consonant -gj- , is always written as -q-

u përgjiq me krenari; me mijëra zoq; shpirtra të liq;

These are morphological contradictions with a dialectical character and are characteristic of the folk language. They have been acquired through the omission of a voiced consonant in the final position or in front of voiceless consonant.

\section{The Omission of the Voiced Consonants in the Body of the Word}

Even in this position, Konica applies the above mentioned morphological contradictions, thus the voiced consonants are represented as voiceless.

The omission of the voiced consonants in the body of the words has happened, without any exception whenever they are situated in front of a voiceless consonant.

- The voiced consonant -dh- is always written as -th- :

trathtinë; të hithta; u huathnë; vothnë; derthnin; mbluathnë; erthtë; ngorthte; të mblithte;

- The voiced consonant -b- is always written as -p- :

humpnë; të mpështetura; në të dhemptë; fuqia mprojtëse; fytyrës së qelptë;

i mpështjellë; të mplidhen; mpështetem; mpas kodrës; mpronte;

- The voiced consonant - $d$ - is always written as -t- :

sëmuntjet; të muntja; e kanë qëntrën; kuvëntet; e shkuntur; në qentër; qëntresë; më tuntnë ethet ;

(q: gj) të squarit; u përgjiqnë ; zoqtë ; i squar ; të Frënqve ; zoqtë; sqon pyllin ;

* Another characteristic is the assimilation of some groups of consonants, be them in the front of body of the word.

This is a frequent phenomenon throughout the southern writers writings, which was portrayed even in Konica in its prose as well as poetry:

- $\quad$ the assimilation of the groups - $\mathrm{mb}$ and -nd:

përmi krye; mi një kodrë; nganonjëherë; as nonjë letër; t’a gdhënin ; as nonjë lajm; nofta ka nër mënt; përmi sheshet e gjakut; mi çatitë e pullazet ;

* In some cases they have been encountered as prepositions in the old form, unassimilated, used in the spatial case, as in the ancient Albanian:

mbë shtëpinë e atit saj; mbë dhè ju hothnë ; mbë dhet kish kartëra ; mbeti e u kalp ndë baltë; ç'ishin mi dhè e nënë dhè ;

mi çatitë e pullazet; të vejë ndëpër gjithë viset; etj.

It should be stressed that in relation to the prepositions mbë ( më ) and $\mathrm{mi}$ ( $\mathrm{mbi}$ ) there exist many linguistic debates. Some linguists think that these prepositions are two different words, while G. Meyer and F. Bopp see them as two variants of the same word. (Xhuvani, 1980)

Therefore, the auxiliary words $m b e ̈$ and $m b i$, are according to them, respectively

"the unstressed and the stressed form of the same preposition".

It should be noted that Konica overuses the consonant group - mb even when they are not needed, be that in the front of body of the word: 
fuqitë e mbëdha ; njerëzit e mbëdhenj ; theatrot e mbëdha ;

lau sytë në një mburim ; me duar në zëmbërë ; i qeshte zëmbra ; etj.

Through the passing of time this group underwent many changes, as it can be seen in the writings of Konica and the other Renaissance writers.

This group can be found in many cases with a new construction, in the accusative case.

This was achieved through the assimilation of the consonant tog - mb into - më . (Çabej, "Hyrje në historinë e gjuhës shqipe ", 1960)

* Another phonetic trait, characteristic for Konica's writings is the wide usage of the initial affix ç- in stead of the corresponding affix sh- or zh- :

fuqi çkatërronjëse; çpifni çpifarakë; të çkëlqyer; içkombëzuar; çpalli; të çkulnin; çkoqitim; çkëmbim të vlershëm ; içquar; të çpëlajnë; çkallmonin ; të çqiteshin; çfaqi menjëherë qëllimin e tij ; ̧̧përbëhet; mos e çponi; të çdukim banditizmën ; pas një çdukje 469 -vjetsh, flamuri ynë valoj i lirë; të çvillojë kompin ;

* In stead of the consonant group -fsh-, he uses the group -psh- ,

pshat ; pshteta ; pshatarakët ; pshinte djersët ; etj (Gjinari, "E folmja e Skraparit ", 1958)

* In relation to the spelling of some foreign words, mainly of Latin origin, the author frequently uses the consonant $-\| l$, in stead of the consonant -1 .

Konica, as an excellent user of these languages has thought that maybe such a spelling and pronunciation form is more appropriate for the Albanian language. He has been mainly influenced by the French language in writing the following words:

në Irllandë; zullutë; dekllaroi; fillosofi; kish mbaruar fillollogjinë;

automobilla; jetën intellektuale; diplloma e dipllomatit; rekllama; lluks;

dekllaratë ; kllasik; biblla kombiare; etj .

What is more, it should be noted that the usage of such a consonant in the spelling of the words we seen until lately in words such as:

kllasa ( punëtore ), dipllomë, lluks, ideollogji, etj.

* The Greek words used in his writings ( he was widely familiar with this language since from an early age) are written by preserving the original pronunciation with the -th letter.

Prometheu; theatrot e mbëdha; i enthusiasmuar; kisha katholike; simpathinë;

theologji; vargje të rithmuar; marathona; theori; Guthenberg;

orthografia; ka një themë të përgjithshme;

Konica was not an extremist puritan. Moreover, in his journalistic writings he has shown to be highly liberal towards foreign words and this is why in many cases he pronounced and wrote them as they are pronounced and written in their source languages from which they have derived. We have come across another phonetic trait. Konica has frequently used the $-q$ consonant instead of the $-k$ consonant.

We think that he might have been influenced by the Greek language that he knew considerably well.

Arqileu i Epirit ; shtëpi arqitekti ; orqestrat sinfonike ; anarqia e guvernës ;

lajthimet e monarqisë; si një arqeolog i Afroditës ; maqina të shtrënjta;

venë dy a tri mijë qillometra larg të dëbuar prej tyre ;

Such words are still used in some Southern regional speeches. Nevertheless, we would stress out the fact that the majority of these words are used by Konica in those writings that were targeted toward a specific class of people with a rather modest cultural formation.

These words were fully comprehensible and therefore articles written with such a language would deeply influence 
his readers. Thus, Konica successfully achieved his goal of changing the spelling of many words in the Albanian language through the etymological transformations he himself made.

\section{References}

Çabej. Eqrem, "Hyrje në historinë e gjuhës shqipe ", 1960 , dispencë , f . 37 - 39 .

Çabej. Eqrem, "Studime rreth etimologjisë së gjuhës shqipe" ,

BUSHT, SSHSH, 1960 , nr. 4. f. 125 - 128

Çeliku. Mehmet, "Kuantiteti i zanoreve të theksuara në të folmet e shqipes ",

Studime Filologjike, 1971 , nr. 3. f. 96.

Dodi. Anastas, "Rreth problemeve të normës në lëmin e fonetikës së shqipes së sotme letrare", Studime filologjike, 1970, nr. 2, f. 70.

Drejtshkrimi i gjuhës shqipe, Tiranë, 1973 , f .44- 46.

Gjinari. Jorgji, « Dialektologjia shqiptare", Tiranë , 1963, f . 82 - 85 .

Gjinari. Jorgji, "Mbi të folmen e Devollit", BUSHT, SSHSH , nr . 4 . 1968 , f . 107-108.

Gjinari. Jorgji, "E folmja e Skraparit” , BUSHT, SSHSH , I , Tiranë , 1958 , f . 89 - 90 .

Konica. Faik, ( Tepeleni ), "La langue des fils de l'aigle ", Paris, 1921, f. 11.

Konica. Faik, « Ç'është liria " , Albania, 1897, III , f. 8.

Topalli. Kolec, "Theksi në gjuhën shqipe " , Tiranë , 1995 , f . 292 - 298

Totoni. Menella, "Shkrimi i ë-së paratheksore ", Kongresi i drejtshkrimit të gjuhës shqipe, II , Tiranë, 1972, f. 39 - 45.

Xhuvani Aleksandër, "Vepra " , I , Tiranë , 1980 , f . 285 , 294. 
